UDC 616-056.52

DOI: $10.21668 /$ health.risk/2019.2.18.eng

\title{
LIPID ACCUMULATION PRODUCT OR LAP AS AN UP-TO-DATE CLINICAL BIOCHEMICAL MARKER OF HUMAN OBESITY
}

\author{
A.M. Kaneva, E.R. Bojko \\ Institute of Physiology, Komi Science Centre, the Ural Branch of the Russian Academy of Sciences, \\ 50 Pervomaiskaya Str., Syktyvkar, 167982, Russian Federation
}

Obesity is a grave medical and social problem causing significant hazards for human health due to frequent occurrence of grave concomitant diseases. Visceral obesity is considered to be the most hazardous. Contemporary diagnostics which allows to reveal visceral obesity both during screening examinations of people who are considered to be conditionally healthy and in patients who suffer from cardiovascular diseases is becoming a very promising trend both in primary and secondary prevention.

The review focuses on an up-to-date marker used to detect visceral obesity, namely, lipid accumulation product or LAP. This index was first introduced by Kahn H.S. in 2005 and is calculated on the basis of two variables, waist circumference $(\mathrm{cm})$ and fasting concentration of triglycerides $(\mathrm{mmol} / \mathrm{l})$. When a biochemical and an anthropometric parameter are applied simultaneously to calculate LAP, it allows not only to assess how fats are distributed in a body but also to reflect functional state of fat tissues.

LAP index is widely used as a marker showing there are metabolic disorders in a body (metabolic syndrome, diabetes, resistance to insulin, or nonalcoholic fatty liver disease) and as a cardiovascular diseases predictor. Besides, LAP index, when used to identify obesity phenotype, allows to assign people with overweight into a "metabolically healthy" category or "metabolically ill" one and to reveal patients suffering from metabolic obesity among people with normal body weight. A lot of research revealed that LAP index had a very good diagnostic and predictive potential as regards metabolic and cardiovascular diseases and was a more precise marker of cardio-metabolic risks than conventional anthropometric parameters. The review highlights LAP value ranges, its sex and age peculiarities, as well as a character and an extent to which LAP values change in case of certain diseases. It also dwells on advantages and drawbacks of LAP practical application.

Key words: lipid accumulation product (LAP), waist circumference, triglycerides, body mass index, obesity, metabolic syndrome, cardiovascular diseases.

The concept "lipid accumulation product" (LAP) was first mentioned in studies by Kahn H.S. [1, 2] where it was considered as a marker of excessive lipid accumulation in adults. LAP index calculation is based on two simple parameters, waist circumference and triglycerides contents in blood plasma on a fasting. Suggested formulas for LAP index calculation are as follows [3]:

$$
\begin{gathered}
\text { LAP for men }=(\mathrm{WC}-65) * \mathrm{TG} \\
\text { LAP for women }=(\mathrm{WC}-58) * \mathrm{TG},
\end{gathered}
$$

where $\mathrm{WC}$ is waist circumference $(\mathrm{cm}), \mathrm{TG}$ are triglycerides (mmol/l), 65 and 58 are minimal waist circumference for men and women obtained via population research.
A wish to implement LAP index into practices is based on previously published researches $[4,5]$ when it was determined that increased waist circumference together with elevated triglycerides contents indicated there was a risk of metabolic diseases. However, waist circumference and triglycerides contents were considered to be dichotomous parameters (standard and above standard) in these researches, whereas LAP index calculation allows to obtain qualitative (continuous) values and it gives wider possibilities for analytical processing and interpretation of all obtained data.

LAP index simultaneously describes anatomic and biochemical changes related to excessive lipids accumulation in adults [3].

(C) Kaneva A.M., Bojko E.R., 2019

Anastasiya M. Kaneva - Doctor of Biological Sciences, Chief researcher at the Ecological and Medical Physiology Department (e-mail: amkaneva@mail.ru; tel.: +7 (8212) 24-14-74; ORCID: https://orcid.org/0000-0002-7789-4300).

Evgenii R. Bojko - Doctor of Medical Sciences, Professor, Director (e-mail: boiko60@inbox.ru; tel.: +7 (8212) 24-14-74; ORCID: https://orcid.org/0000-0002-8027-898X). 
An increase in fats contents in a body usually leads to obesity. Obesity is excessive body weight and it is usually assessed as per body mass index (BMI). However, BMI, being a ratio of a person's weight to his or her height, doesn't take into account somatotype, a ratio between fat and muscle weight in a body, and fat tissue distribution; all that significantly decreases its value for an objective overweight evaluation. Thus, a study that was performed on 1,400 people allowed to detect significant discrepancies between results of determining obesity with BMI and x-ray absorptiometry [6].

Unfavorable outcomes that obesity might have are less related to overall fat contents in a body than to peculiarities of its distribution. Basically, there are three types of fat tissue: subcutaneous fat, subfacial fat, and visceral fat. Excessive fat accumulation in the upper part of a body and on the stomach leads to abdominal obesity. In its turn, abdominal obesity is divided into visceral obesity and subcutaneous-abdominal one. Abdominal obesity is thought to be the most hazardous; it usually develops due to excessive increase in visceral fat contents. When such obesity occurs, excessive visceral fat exerts pressure on internal tissues, causes functional disorders in them, and deteriorates blood circulation and lymph flow. Besides, visceral fat tissue differs from subcutaneous fat as per adipocytes type, their endocrine function, lipolytic activity, and sensitivity to insulin and other hormones. Visceral fat tissue, due to its high lipolytic activity, promotes excessive input of free fat acids in big quantities into portal veins and peripheral blood flow; it, in its turn, causes hypertriglyceridemia and atherogenic dyslipidemia, resistance to insulin, hyperglycemia, and hyperinsulinemia [7,8]. The simplest way to indirectly determine abdominal obesity is to perform anthropometric waist circumference measurement. However, waist circumference measurement doesn't allow determining abdominal obesity type [9, 10], while combine application of waist circum- ference and triglycerides contents in a formula for LAP index calculation gives an opportunity to apply this index as a marker of metabolic disorders, abdominal-visceral obesity and related diseases.

LAP index in widely used as a marker showing metabolic syndrome [11, 12], resistance to insulin $[13,14]$, diabetes [15], nonalcoholic fatty liver disease [16, 17], hormonal disorders [18, 19], as well as risk of hypertension [20, 21], stroke [22], renal dysfunction [23, 24], and cardiovascular diseases [25]. The index is also successfully applied to identify people who run high metabolic risks in case of certain diseases (psoriasis, polycystic ovarian disease, and hyposomatotropism) $[18,26,27]$. Besides, researchers revealed a correlation between LAP index and blood lipid profile atherogenicity and lipoproteins sizes [28], blood viscosity [29], blood pressure parameters [30,31], left ventricle geometry [32], thyreotrophin concentration [33], alcohol intake [34, 35], smoking [36], physical activity $[37,38]$, alanine aminotransferase level [39], inflammatory biomarkers, and adiponectin [40], and overall mortality as well [41].

LAP index values vary within a wide range. Among population studies, the greatest LAP index variations were detected among Iran population (from 0.62 to 570.26 $\mathrm{cm} . \mathrm{mmol} / 1$ in men $(\mathrm{n}=3,682)$ and from 0.56 to $620.39 \mathrm{~cm} . \mathrm{mmol} / 1$ in women $(\mathrm{n}=4,989))$ [42]. Significant variations in LAP index values were also detected among people living in Kenya (from 0 to $388.87 \mathrm{~cm} . \mathrm{mmol} / 1$ in men $(n=255)$ and from 3.30 до 205.54 $\mathrm{cm} . \mathrm{mmol} / 1$ in women $(\mathrm{n}=273))$ [43]; among elderly males in Poland (aged 50-75, $\mathrm{n}=313$ ) (from 7.36 to $338.97 \mathrm{~cm} . \mathrm{mmol} / \mathrm{l}$ ) [19]; and among young women (younger than 40, $\mathrm{n}=2,810$ ) in Korea (from 0 to 252.0 cm.mmol/1) [44]. However, a significantly wider range of LAP index variations is detected when it comes to patients with cardiovascular pathologies $(0.8-1,020 \mathrm{~cm} . \mathrm{mmol} / 1$ in men $(\mathrm{n}=3,604)$ and $0.7-1,020 \mathrm{~cm} \cdot \mathrm{mmol} / 1$ in women $(n=2,320)$ respectively) [41]. 
Table 1

Comparative assessment of LAP index among men and women as per literature data

\begin{tabular}{|c|c|c|c|c|c|c|}
\hline \multirow{3}{*}{ References } & \multirow{3}{*}{ Country } & \multicolumn{4}{|c|}{ LAP index (cm.mmol/1) } & \multirow{3}{*}{$\mathrm{p}$} \\
\hline & & \multicolumn{2}{|c|}{ Men } & \multicolumn{2}{|l|}{ Women } & \\
\hline & & $\begin{array}{c}\mathrm{M} \pm \mathrm{SD} \text { or } \\
\mathrm{Me}(25 \% ; 75 \%)\end{array}$ & $\mathrm{n}$ & $\begin{array}{c}\mathrm{M} \pm \mathrm{SD} \text { or } \\
\mathrm{Me}(25 \% ; 75 \%)\end{array}$ & $\mathrm{n}$ & \\
\hline Xia C. et al., 2012 [13] & China & $25.96(14.2 ; 41.97)$ & 1,510 & $23.99(13.09 ; 40.12)$ & 1,014 & 0.074 \\
\hline Omuse G. et al., 2017 [43] & Kenya & $29.52(40.95) \#$ & 255 & $23.97(29.69) \#$ & 273 & 0.055 \\
\hline Wakabayashi I., 2014 [47] & Japan & $23.7(12.1 ; 44.0)$ & 35,684 & $16.4(8.9 ; 30.1)$ & 18,793 & $<0.01$ \\
\hline Chen Y. et al., 2018 [33] & China & $26.69(34.72)$ & 3,786 & $22.88(29.46)$ & 4,941 & $<0.001$ \\
\hline Tripolino C. et al., 2017 [29] & Italy & $42.7 \pm 28.5$ & 193 & $29.1 \pm 16.1$ & 151 & $<0.001$ \\
\hline Abulmeaty M.M. et al., 2017 [46] & $\begin{array}{l}\text { Saudi } \\
\text { Arabia }\end{array}$ & $62.17 \pm 54.64$ & 167 & $77.37 \pm 60.78$ & 223 & 0.044 \\
\hline Chiang J.K. et al., 2012 [48] & Taiwan & $23.0 \pm 23.2$ & 266 & $28.6 \pm 19.3$ & 247 & 0.001 \\
\hline Wang H. et al., 2018 [32] & China & $21.95(10.71 ; 43.60)$ & 5,179 & $28.31(16.17 ; 50.95)$ & 6,079 & $<0.001$ \\
\hline Motamed N. et al., 2016 [45] & Iran & $47.34 \pm 45.55$ & 3,281 & $58.73 \pm 52.86$ & 2,516 & $<0.001$ \\
\hline
\end{tabular}

Note: data are given either as a mean and standard deviation $(\mathrm{M} \pm \mathrm{SD})$, or median and $25 \%$ and $75 \%$ percentiles $(\mathrm{Me}(25 \% ; 75 \%))$; \# means data are given as median and interquartile spread.

According to some research, LAP index values tend to be higher in men than in women [29, 33], whereas other studies, on the contrary, contain data on higher LAP index values to be more typical for women $[45,46]$ (Table 1). Some authors state there are no age-related differences in LAP index values [13, 43].

Bearing in mind that the above data differ greatly and are mostly inconsistent, it is impossible to reveal any age-related peculiarities in LAP index changes as per results obtained in various research. Meanwhile, there are only few studies that focus on age dynamics of LAP index changes; besides, they are significantly different as per researches design. I. Wakabayashi [47] performed his research on men $(n=35,684)$ and women $(\mathrm{n}=18,793)$ who were divided into four age groups (aged 35-39, 40-49, 50-59 and 60-70). It was detected that LAP index increased with age among women, while its maximum values were detected among men aged 40-49 and then they went down. This ambiguous age dynamics of parameters among men and women resulted in LAP index values being lower among women than among men in younger age groups, but higher in older ones. H.S. Kahn [et al.] [49] gave average LAP index values for two age groups (18-44 and 45-64) that amounted to 28.8 $(15.6 ; 56.6)$ and $50.2(30.2 ; 84.9) \mathrm{cm} . \mathrm{mmol} / 1$ in men, and $20.8(11.5 ; 38.4)$ and $47.6(25.3$; $82.8) \mathrm{cm} . \mathrm{mmol} / \mathrm{l}$ in women. Similar agerelated dynamics of LAP index values was detected in studies by S.H. Fu [et al.] [50], and H. Joshi [et al.] [51]. Average LAP index among people living in China who were younger than $60(n=694)$ amounted to 35.92 $(20.33$; 61.74) $\mathrm{cm} . \mathrm{mmol} / \mathrm{l}$; and they significantly grew in people older than $60(\mathrm{n}=846)$ $(p=0.001)$, up to $41.55 \quad(25.90 ; 66.13)$ $\mathrm{cm} . \mathrm{mmol} / 1$ [50]. LAP index amounted to $21.43 \pm 14.34 \mathrm{~cm} . \mathrm{mmol} / 1$ in young people (younger than $40, n=1,180$ ) living in India, and it was equal to $31.42 \pm 18.11 \mathrm{~cm} . \mathrm{mmol} / 1$ among those older than $40(n=1,003)$ [51]. Therefore, basing on the results of all the researches outlined above, we can come to a conclusion that LAP index values, as a rule, tend to increase with age. Obviously, it is due to a fact that waist circumference and triglycerides contents applied for LAP index calculation also tend to go up with age. 
A significant number of research that dwells on correlations between LAP index and various diseases focuses on metabolic syndrome. Researchers determined a diagnostic potential (sensitivity, specificity, positive and negative predictive value) of LAP index that could be applied to predict the disease and detected that it was an "ideal" marker to identify metabolic syndrome [45, $48,52,53]$. Some studies revealed that LAP index predicted metabolic syndrome with greater precision in comparison with anthropometric measurements (BMI or waist circumference) $[11,13,45,54]$. Nevertheless, some researchers recommend not to overestimate LAP index predictive value as regards metabolic syndrome. When it is calculated, waist circumference and triglycerides contents are applied, but they are also key components in metabolic syndrome and it can determine an internal relation between the index and the disease [55]. Besides, there are data on absence of any advantages LAP index might have against anthropometric parameters for metabolic diseases prediction $[56,57]$.

Diagnostic precision of LAP index seems to depend on age and sex. Some researchers revealed a greater correlation between LAP index values and risks of diseases among women than among men [47, 58]. Diagnostic precision of LAP index was significantly higher for young people of both sexes than for elderly ones when diabetes and non-alcoholic fatty liver disease were identified $[17,47]$. On the contrary, LAP index precision as visceral obesity marker was higher among elderly people [59].

Despite LAP index is widely applied nowadays to assess cardiovascular and metabolic risks, there is no any conventional standard for this index. Researchers, as a rule, calculate optimal threshold LAP index values to predict diseases development basing on ROC-curves (Receiver Operator Characteristic). This procedure allows to determine a threshold value that is the most adequate point for separating one diagnosed group from another. However, optimal threshold LAP index values obtained for each particular disease are different in different studies; it is due to examined populations being different as per sex, age, ethnic groups, and health state of examined people.

Considerable variations are also observed for average LAP index values for different diseases (Table 2).

LAP index is rarely used in Russia. There was a large-scale study entitled "Epidemiology of cardiovascular diseases and risk factors causing thin in the RF regions" (ESSE-RF) that involved LAP index calculating. The study was accomplished in 20122014 in 13 regions in Russia by Drapkina O.M. et al, and Shal'nova S.A. et al. There were also some clinical studies (Khripun I.A. et al.; Kornoukhova L.A.). According to data collected via ESSE RF that comprised 20,878 people aged 25-64 (8,058 men and 12,820 women), average LAP index values amounted to $45.5 \pm 0.88$ and $35.4 \pm 0.31 \mathrm{~cm} . \mathrm{mmol} / 1$ among men and women respectively who didn't have ischemic heart disease or pancreatic diabetes [63-66].

LAP index has an advantage over other anthropometric parameters as it provides a possibility to identify obesity phenotype. Thus, LAP index application allows to divide people with overweight into "metabolically healthy" and "metabolically ill" [67]. At the same time, LAP index enables detecting people with metabolic obesity among those with normal body weight [68].

If a person is healthy but still has metabolic obesity, then excessive fat accumulation in him or her doesn't lead to unfavorable metabolic effects such as resistance to insulin, disrupted tolerance to dextrose, dyslipidemia, or primary hypertension. As per literature data, prevalence of metabolically healthy obesity in Europe varies from $10 \%$ to $45 \%$ among people with obesity [69]. Precise diagnostics of obesity phenotype allows to make a correct choice on a set of therapeutic activities aimed at helping a patient to lose weight. At the same time, early detection of 
Average LAP index values for different diseases as per literature data

\begin{tabular}{|c|c|c|c|c|c|c|}
\hline \multirow{3}{*}{ References, disease } & \multirow{3}{*}{ Country } & \multirow{3}{*}{ Sex } & \multicolumn{4}{|c|}{ LAP index $(\mathrm{cm} \mathrm{mmol} / \mathrm{l})$} \\
\hline & & & \multicolumn{2}{|c|}{ Control } & \multicolumn{2}{|l|}{ Test } \\
\hline & & & $\begin{array}{c}\mathrm{M} \pm \mathrm{SD} \text { or } \\
\mathrm{Me}(25 \% ; 75 \%)\end{array}$ & $\mathrm{n}$ & $\begin{array}{c}\mathrm{M} \pm \mathrm{SD} \text { or } \\
\mathrm{Me}(25 \% ; 75 \%)\end{array}$ & $\mathrm{n}$ \\
\hline $\begin{array}{l}\text { Li R. et al., } 2018 \text { [12]; metabolic } \\
\text { syndrome }\end{array}$ & China & $\mathrm{m}+\mathrm{f}$ & $21.58 \pm 15.04$ & 617 & $53.47 \pm 30.22$ & 375 \\
\hline $\begin{array}{l}\text { Cheng Y.L. et al., } 2017 \text { [60]; } \\
\text { metabolic syndrome }\end{array}$ & Taiwan & $\mathrm{m}+\mathrm{f}$ & $23.61 \pm 18.57$ & 21,233 & $64.22 \pm 43.52$ & 8,564 \\
\hline $\begin{array}{l}\text { Mazidi M. et al., } 2018 \text { [14]; } \\
\text { resistance to insulin }\end{array}$ & The USA & $\mathrm{m}+\mathrm{f}$ & $53.3 \pm 0.6$ & 17,403 & $127.2 \pm 0.5$ & 915 \\
\hline $\begin{array}{l}\text { Kavaric N. et al., } 2018 \text { [57]; } \\
\text { II type pancreatic diabetes }\end{array}$ & $\begin{array}{l}\text { Monte } \\
\text { Negro }\end{array}$ & $\mathrm{m}+\mathrm{f}$ & $44.34(38.14 ; 51.53)$ & 119 & $82.87(76.69 ; 90.73)$ & 180 \\
\hline $\begin{array}{l}\text { Dai H. et al., } 2017 \text { [17]; non- } \\
\text { alcoholic fatty liver disease }\end{array}$ & China & $\mathrm{m} / \mathrm{f}$ & $\begin{array}{l}23.7 \pm 22.0 \\
16.6 \pm 15.5\end{array}$ & $\begin{array}{l}10,266 \\
18,043\end{array}$ & $\begin{array}{l}62.4 \pm 59.7 \\
49.4 \pm 41.2\end{array}$ & $\begin{array}{l}8,070 \\
4,080\end{array}$ \\
\hline $\begin{array}{l}\text { Wang H. et al., } 2017 \text { [61]; } \\
\text { ischemic stroke }\end{array}$ & China & $\mathrm{m} / \mathrm{f}$ & $\begin{array}{l}35.24(21.78 ; 42.93) \\
40.19(15.93 ; 49.49) \\
\end{array}$ & $\begin{array}{l}5,087 \\
5,904 \\
\end{array}$ & $\begin{array}{l}43.49(29.76 ; 50.27) \\
65.21(31.51 ; 88.64) \\
\end{array}$ & $\begin{array}{l}166 \\
188 \\
\end{array}$ \\
\hline $\begin{array}{l}\text { Li R. et al., } 2017 \text { [58]; atheroscle- } \\
\text { rotic stenosis of intracranial vessels }\end{array}$ & China & $\mathrm{m} / \mathrm{f}$ & \begin{tabular}{|l|}
$31.73 \pm 36.73$ \\
$37.03 \pm 25.65$ \\
\end{tabular} & $\begin{array}{l}339 \\
411 \\
\end{array}$ & $\begin{array}{l}32.83 \pm 28.74 \\
45.99 \pm 37.85 \\
\end{array}$ & $\begin{array}{l}56 \\
39 \\
\end{array}$ \\
\hline $\begin{array}{l}\text { Wang H. et al., } 2018 \text { [21]; } \\
\text { hypertension }\end{array}$ & China & $\mathrm{m} / \mathrm{f}$ & \begin{tabular}{|r|}
$17.10(8.45 ; 34.35)$ \\
$21.79(12.86 ; 38.13)$ \\
\end{tabular} & $\begin{array}{l}2,326 \\
3,130 \\
\end{array}$ & $\begin{array}{l}27.46(13.98 ; 51.38) \\
37.27(21.78 ; 64.04) \\
\end{array}$ & $\begin{array}{l}2,732 \\
2,952 \\
\end{array}$ \\
\hline $\begin{array}{l}\text { Rashid N. et al., } 2017 \text { [62]; } \\
\text { polycystic ovarian disease }\end{array}$ & India & $\mathrm{m} / \mathrm{f}$ & $25.77 \pm 14.13$ & 45 & $40.37 \pm 22.17$ & 95 \\
\hline $\begin{array}{l}\text { Ganguly S. et al., } 2018 \text { [26]; } \\
\text { psoriasis }\end{array}$ & India & $\mathrm{m}+\mathrm{f}$ & $23.79 \pm 13.02$ & 42 & $46.42 \pm 27.2$ & 40 \\
\hline $\begin{array}{l}\text { Chan L. et al., } 2016 \text { [18]; } \\
\text { hyposomatotropism }\end{array}$ & China & $\mathrm{m}+\mathrm{f}$ & $21.30(10.35 ; 32.48)$ & 75 & $43.93(18.74 ; 69.31)$ & 75 \\
\hline
\end{tabular}

Note: data are given either as a mean and standard deviation $(\mathrm{M} \pm \mathrm{SD})$ or median and $25 \%$ and $75 \%$ percentiles $(\mathrm{Me}(25 \% ; 75 \%))$.

"metabolically unhealthy people" with normal body weight can make prediction and prevention of diabetes and cardiovascular diseases much more efficient.

So, LAP index is a marker that reflects joint anatomic and biochemical changes that are related to excessive lipid accumulation in a body. It is an appropriate instrument to detect predisposition to metabolic and cardiovascular diseases. LAP index is easy-to-use, doesn't require any expensive laboratory tests, and should be included into laboratory screening as an early, precise, and cheap metabolic risk predictor. Nevertheless, diagnostic significance, informative values, and possibilities of LAP index application in everyday practices to assess excessive lipids accumulation in a body require further exploration. LAP index has its drawbacks such as low comparability of results obtained in different research, absence of standards for its assessment, and difficulties related to interpreting data at an individual level.

Funding. The research was accomplished within Project No. 18-7-8-7 (No. GR AAAA-A18118012290366-9) of Fundamental Scientific Research Program for 2018-2020.

Conflict of interests. The authors state there is no any conflict of interests. 


\section{References}

1. Kahn H.S. Estimating adult metabolic risk from a lipid accumulation product. Am. J. Epidemiol., 2004, vol. 159, no. 11, pp. 14.

2. Kahn H.S. The lipid accumulation product is better than body mass index for identifying diabetes. Am. J. Epidemiol., 2005, vol. 161, no. 11, pp. 51.

3. Kahn H.S. The «lipid accumulation product» performs better than the body mass index for recognizing cardiovascular risk: a population-based comparison. BMC Cardiovasc Disord, 2005, vol. 5, pp. 26. DOI: 10.1186/1471-2261-5-26

4. Lemieux I., Pascot A., Couillard C., Lamarche B., Tchernof A., Almeras N. [et al.]. Hypertriglyceridemic waist: A marker of the atherogenic metabolic triad (hyperinsulinemia; hyperapolipoprotein B; small, dense LDL) in men? Circulation, 2000, vol. 102, no. 2, pp. 179-184.

5. Kahn H.S., Valdez R. Metabolic risks identified by the combination of enlarged waist and elevated triacylglycerols. Am. J. Clin. Nutr., 2003, vol. 78, no. 5, pp. 928-934. DOI: 10.1093/ ajen/78.5.928

6. Shah N.R., Braverman E.R. Measuring adiposity in patients: the utility of body mass index (BMI), percent body fat, and leptin. PLoS One, 2012, vol. 7, no. 4, pp. e33308. DOI: 10.1371/ journal.pone. 0033308

7. Ibrahim M.M. Subcutaneous and visceral adipose tissue: structural and functional differences. Obes Rev, 2010, vol. 11, no. 1, pp. 11-18. DOI: 10.1111/j.1467-789X.2009.00623.x

8. Ebbert J.O., Jensen M.D. Fat depots, free fatty acids, and dyslipidemia. Nutrients, 2013, vol. 5, no. 2, pp. 498-508. DOI: 10.3390/nu5020498

9. Després J.P., Lemieux I., Bergeron J., Pibarot P., Mathieu P., Larose E. [et al.]. Abdominal obesity and the metabolic syndrome: contribution to global cardiometabolic risk. Arterioscler Thromb. Vasc. Biol., 2008, vol. 28, no. 6, pp. 1039-1049. DOI: 10.1161/ATVBAHA.107.159228

10. Wang H., Liu A., Zhao T., Gong X., Pang T., Zhou Y. [et al.]. Comparison of anthropometric indices for predicting the risk of metabolic syndrome and its components in Chinese adults: a prospective, longitudinal study. BMJ Open, 2017, vol. 7, no. 9, pp. e016062. DOI: 10.1136/bmjopen2017-016062

11. Ray L., Ravichandran K., Nanda S.K. Comparison of lipid accumulation product index with body mass index and waist circumference as a predictor of metabolic syndrome in Indian population. Metab. Syndr. Relat.Disord., 2018, vol. 16, no. 5, pp. 240-245. DOI: 10.1089/met.2017.0119

12. Li R., Li Q., Cui M., Yin Z., Li L., Zhong T. [et al.]. Clinical surrogate markers for predicting metabolic syndrome in middle-aged and elderly Chinese. J. Diabetes Investig, 2018, vol. 9, no. 2, pp. 411-418. DOI: $10.1111 /$ jdi. 12708

13. Xia C., Li R., Zhang S., Gong L., Ren W., Wang Z., Li Q. Lipid accumulation product is a powerful index for recognizing insulin resistance in non-diabetic individuals. Eur. J. Clin. Nutr., 2012, vol. 66, no. 9, pp. 1035-1038. DOI: 10.1038/ejen.2012.83

14. Mazidi M., Kengne A.P., Katsiki N., Mikhailidis D.P., Banach M. Lipid accumulation product and triglycerides/glucose index are useful predictors of insulin resistance. J. Diabetes Complications, 2018, vol. 32, no. 3, pp. 266-270. DOI: 10.1016/j.jdiacomp.2017.10.007

15. Wakabayashi I., Daimon T. A strong association between lipid accumulation product and diabetes mellitus in Japanese women and men. J. Atheroscler. Thromb., 2014, vol. 21, no. 3, pp. 282-288. DOI: $10.5551 /$ jat.20628

16. Bedogni G., Kahn H.S., Bellentani S., Tiribelli C. A simple index of lipid overaccumulation is a good marker of liver steatosis. BMC Gastroenterol, 2010, vol. 10, pp. 98. DOI: 10.1186/ 1471-230X-10-98

17. Dai H., Wang W., Chen R., Chen Z., Lu Y., Yuan H. Lipid accumulation product is a powerful tool to predict non-alcoholic fatty liver disease in Chinese adults. Nutr Metab (Lond), 2017, vol. 14, pp. 49. DOI: 10.1186/s12986-017-0206-2

18. Chan L., Xue H., Xiaoya Z., Jiajia X., Wei R., Linman L. [et al.]. Lipid accumulation product: a simple and accurate index for predicting metabolic syndrome in patients with adult growth 
hormone deficiency. Exp. Clin. Endocrinol. Diabetes, 2016, vol. 124, no. 4, pp. 220-224. DOI: $10.1055 / \mathrm{s}-0035-1569402$

19. Rotter I., Rył A., Szylińska A., Pawlukowska W., Lubkowska A., Laszczyńska M. Lipid accumulation product (LAP) as an index of metabolic and hormonal disorders in aging men. Exp. Clin. Endocrinol. Diabetes, 2017, vol. 125, no. 3, pp. 176-182. DOI: 10.1055/s-0042-116071

20. Gao X., Wang G., Wang A., Xu T., Tong W., Zhang Y. Comparison of lipid accumulation product with body mass index as an indicator of hypertension risk among Mongolians in China. Obes. Res. Clin. Pract., 2013, vol. 7, no. 4, pp. e308-314. DOI: 10.1016/j.orcp.2012.02.002

21. Wang H., Chen Y., Sun G., Jia P., Qian H., Sun Y. Validity of cardiometabolic index, lipid accumulation product, and body adiposity index in predicting the risk of hypertension in Chinese population. Postgrad Med., 2018, vol. 130, no. 3, pp. 325-333. DOI: 10.1080/00325481.2018.1444901

22.Zhong C., Xia W., Zhong X., Xu T., Li H., Zhang M. [et al.]. Lipid accumulation product and hypertension related to stroke: a 9.2-year prospective study among Mongolians in China. $J$. Atheroscler. Thromb., 2016, vol. 23, no. 7, pp. 830-838. DOI: 10.5551/jat.33514

23. Zhang K., Li Q., Chen Y., Wang N., Lu Y. Visceral adiposity and renal function: an observational study from SPECT-China. Lipids Health Dis., 2017, vol. 16, pp. 205. DOI: 10.1186/s12944017-0597-0

24. Dai D., Chang Y., Chen Y., Chen S., Yu S., Guo X., Sun Y. Visceral adiposity index and lipid accumulation product index: two alternate body indices to identify chronic kidney disease among the rural population in northeast China. Int J. Environ. Res. Public. Health, 2016, vol. 13, no. 12 , pp. 1231. DOI: 10.3390/ijerph13121231

25. Kyrou I., Panagiotakos D.B., Kouli G.M., Georgousopoulou E., Chrysohoou C., Tsigos C. [et al.]. Lipid accumulation product in relation to 10-year cardiovascular disease incidence in Caucasian adults: The ATTICA study. Atherosclerosis, 2018, vol. 279, pp. 10-16. DOI: 10.1016/j.atherosclerosis.2018.10.015

26. Ganguly S., Ray L., Kuruvila S., Nanda S.K., Ravichandran K. Lipid accumulation product index as visceral obesity indicator in psoriasis: a case-control study. Indian J. Dermatol, 2018, vol. 63, no. 2, pp. 136-140. DOI: 10.4103/ijd.IJD_315_16

27. Glintborg D., Andersen M. Medical comorbidity in polycystic ovary syndrome with special focus on cardiometabolic, autoimmune, hepatic and cancer diseases: an updated review. Curr. Opin. Obstet. Gynecol., 2017, vol. 29, no. 6, pp. 390-396. DOI: 10.1097/GCO.0000000000000410

28. Cartolano F.C., Pappiani C., Freitas M.C.P., Figueiredo Neto A.M., Carioca A.A.F., Damasceno N.R.T. Is lipid accumulation product associated with an atherogenic lipoprotein profile in Brazilian subjects? Arq. Bras. Cardiol., 2018, vol. 110, no. 5, pp. 339-347. DOI: 10.5935/abc.20180054

29. Tripolino C., Irace C., Carallo C., Scavelli F.B., Gnasso A. Body fat and blood rheology: Evaluation of the association between different adiposity indices and blood viscosity. Clin. Hemorheol Microcirc., 2017, vol. 65, no. 3, pp. 241-248. DOI: 10.3233/CH-16172

30. Wakabayashi I. Associations of blood lipid-related indices with blood pressure and pulse pressure in middle-aged men. Metab. Syndr. Relat. Disord., 2015, vol. 13, no. 1, pp. 22-28. DOI: 10.1089/met.2014.0093

31. Bhargava A. Dietary modifications and lipid accumulation product are associated with systolic and diastolic blood pressures in the women's health trial: Feasibility study in minority populations. Curr. Hypertens. Rep., 2018, vol. 20, no. 6, pp. 50. DOI: 10.1007/s11906-018-0846-2

32. Wang H., Sun Y., Li Z., Guo X., Chen S., Ye N. [et al.]. Gender-specific contribution of cardiometabolic index and lipid accumulation product to left ventricular geometry change in general population of rural China. BMC Cardiovasc. Disord., 2018, vol. 18, no. 1, pp. 62. DOI: 10.1186/ s12872-018-0798-0

33. Chen Y., Chen Y., Wang N., Chen C., Nie X., Li Q. [et al.]. Thyroid stimulating hormone within the reference range is associated with visceral adiposity index and lipid accumulation product: A population-based study of SPECT-China. Horm Metab. Res., 2018, vol. 50, no. 1, pp. 29-36. DOI: $10.1055 / \mathrm{s}-0043-122235$ 
34. Wakabayashi I. Associations between heavy alcohol drinking and lipid-related indices in middle-aged men. Alcohol, 2013, vol. 47, no. 8, pp. 637-642. DOI: 10.1016/j.alcohol.2013.10.001

35. Li X.X., Zhao Y., Huang L.X., Xu H.X., Liu X.Y., Yang J.J. [et al.]. Effects of smoking and alcohol consumption on lipid profile in male adults in northwest rural China. Public Health, 2018, vol. 157, pp. 7-13. DOI: 10.1016/j.puhe.2018.01.003

36. Wakabayashi I. Smoking and lipid-related indices in patients with diabetes mellitus. Diabet Med., 2014, vol. 31, no. 7, pp. 868-878. DOI: 10.1111/dme.12430

37. Green A.N., McGrath R., Martinez V., Taylor K., Paul D.R., Vella C.A. Associations of objectively measured sedentary behavior, light activity, and markers of cardiometabolic health in young women. Eur. J. Appl. Physiol., 2014, vol. 114, no. 5, pp. 907-919. DOI: 10.1007/s00421-014-2822-0

38. Mario F.M., Graff S.K., Spritzer P.M. Habitual physical activity is associated with improved anthropometric and androgenic profile in PCOS: a cross-sectional study. J. Endocrinol. Invest., 2017, vol. 40, no. 4, pp. 377-384. DOI: 10.1007/s40618-016-0570-1

39. Ji B.L., Li R., Zhang S.H., Gong L.L., Wang Z.H., Ren W., Li Q.F. The lipid accumulation product is highly related to serum alanine aminotransferase level in male adults. Nutr. Res., 2012, vol. 32 , no. 8 , pp. 581-587. DOI: $10.1016 /$ j.nutres.2012.06.019

40. De Oliveira A., Hermsdorff H.H., Cocate P.G., Santos E.C., Bressan J., Natali A.J. Accuracy of plasma interleukin-18 and adiponectin concentrations in predicting metabolic syndrome and cardiometabolic disease risk in middle-age Brazilian men. Appl. Physiol. Nutr. Metab., 2015, vol. 40, no. 10, pp. 1048-1055. DOI: 10.1139/apnm-2014-0487

41. Ioachimescu A.G., Brennan D.M., Hoar B.M., Hoogwerf B.J. The lipid accumulation product and all-cause mortality in patients at high cardiovascular risk: a PreCIS database study. Obesity (Silver Spring), 2010, vol. 18, no. 9, pp. 1836-1844. DOI: 10.1038/oby.2009.453

42. Bozorgmanesh M., Hadaegh F., Azizi F. Diabetes prediction, lipid accumulation product, and adiposity measures; 6-year follow-up: Tehran lipid and glucose study. Lipids Health Dis., 2010, vol. 9, pp. 45. DOI: 10.1186/1476-511X-9-45

43. Omuse G., Maina D., Hoffman M., Mwangi J., Wambua C., Kagotho E. [et al.]. Metabolic syndrome and its predictors in an urban population in Kenya: A cross sectional study. BMC Endocr. Disord., 2017, vol. 17, no. 1, pp. 37. DOI: 10.1186/s12902-017-0188-0

44. Oh J.Y., Sung Y.A., Lee H.J. The lipid accumulation product as a useful index for identifying abnormal glucose regulation in young Korean women. Diabet Med., 2013, vol. 30, no. 4, pp. 436-442. DOI: $10.1111 /$ dme.12052

45. Motamed N., Razmjou S., Hemmasi G., Maadi M., Zamani F. Lipid accumulation product and metabolic syndrome: a population-based study in northern Iran, Amol. J. Endocrinol. Invest., 2016, vol. 39, no. 4, pp. 375-382. DOI: 10.1007/s40618-015-0369-5

46. Abulmeaty M.M., Almajwal A.M., Almadani N.K., Aldosari M.S., Alnajim A.A., Ali S.B. [et al.]. Anthropometric and central obesity indices as predictors of long-term cardiometabolic risk among Saudi young and middle-aged men and women. Saudi. Med. J., 2017, vol. 38, no. 4, pp. 372-380. DOI: $10.15537 / \mathrm{smj} .2017 .4 .18758$

47. Wakabayashi I. Influence of age and gender on lipid accumulation product and its relation to diabetes mellitus in Japanese. Clin. Chim. Acta., 2014, vol. 431, pp. 221-226. DOI: 10.1016/ j.cca.2014.02.002

48. Chiang J.K., Koo M. Lipid accumulation product: a simple and accurate index for predicting metabolic syndrome in Taiwanese people aged 50 and over. BMC Cardiovasc. Disord., 2012, vol. 12, pp. 78. DOI: 10.1186/1471-2261-12-78

49. Kahn H.S., Bullard K.M., Barker L.E., Imperatore G. Differences between adiposity indicators for predicting all-cause mortality in a representative sample of United States non-elderly adults. PLoS One, 2012, vol. 7, no. 11, pp. e50428. DOI: 10.1371/journal.pone.0050428

50. Fu S., Luo L., Ye P., Xiao W. Multimarker analysis for new biomarkers in relation to central arterial stiffness and hemodynamics in a Chinese community-dwelling population. Angiology, 2015, vol. 66, no. 10, pp. 950-956. DOI: 10.1177/0003319715573910 
51. Joshi H., Shah K., Patel P., Prajapati J., Parmar M., Doshi D., Chaurushia S. Novel indexes for diagnosing metabolic syndrome in apparently healthy Gujarati Asian Indians: a cross-sectional study. QJM, 2016, vol. 109, no. 11, pp. 717-722. DOI: 10.1093/qjmed/hcw056

52. Xiang S., Hua F., Chen L., Tang Y., Jiang X., Liu Z. Lipid accumulation product is related to metabolic syndrome in women with polycystic ovary syndrome. Exp. Clin. Endocrinol. Diabetes., 2013, vol. 121, no. 2, pp. 115-118. DOI: 10.1055/s-0032-1333261

53. Taverna M.J., Martínez-Larrad M.T., Frechtel G.D., Serrano-Ríos M. Lipid accumulation product: a powerful marker of metabolic syndrome in healthy population. Eur. J. Endocrinol., 2011, vol. 164 , no. 4 , pp. 559-567. DOI: 10.1530/EJE-10-1039

54. Hosseinpanah F., Barzin M., Erfani H., Serahati S., Ramezani Tehrani F., Azizi F. Lipid accumulation product and insulin resistance in Iranian PCOS prevalence study. Clin. Endocrinol. (Oxf), 2014, vol. 81, no. 1, pp. 52-57. DOI: 10.1177/2047487314558771

55. Tian S., Xu Y., Han F. Higher predictability of the lipid accumulation product than commonly used anthropometric parameters partly due to its definition. Clin. Nutr., 2017, vol. 36, no. 3, pp. 909. DOI: 10.1016/j.clnu.2017.03.001

56. Bozorgmanesh M., Hadaegh F., Azizi F. Predictive performances of lipid accumulation product vs. adiposity measures for cardiovascular diseases and all-cause mortality, 8.6-year followup: Tehran lipid and glucose study. Lipids Health Dis., 2010, vol. 9, pp. 100. DOI: 10.1186/1476$511 X-9-100$

57. Kavaric N., Klisic A., Ninic A. Are visceral adiposity index and lipid accumulation product reliable indices for metabolic disturbances in patients with type 2 diabetes mellitus? J. Clin. Lab. Anal., 2018, vol. 32, no. 3, pp. e22283. DOI: 10.1002/jcla.22283

58. Li R., Li Q., Cui M., Ying Z., Li L., Zhong T. [et al.]. Visceral adiposity index, lipid accumulation product and intracranial atherosclerotic stenosis in middle-aged and elderly Chinese. Sci. Rep., 2017, vol. 7, no. 1, pp. 7951. DOI: 10.1038/s41598-017-07811-7

59. Roriz A.K., Passos L.C., De Oliveira C.C., Eickemberg M., Moreira P.A., Sampaio L.R. Evaluation of the accuracy of anthropometric clinical indicators of visceral fat in adults and elderly. PLoS One, 2014, vol. 9, no. 7, pp. e103499. DOI: 10.1371/journal.pone.0103499

60. Cheng Y.L., Wang Y.J., Lan K.H., Huo T.I., Huang Y.H., Su C.W. [et al.]. Fatty liver index and lipid accumulation product can predict metabolic syndrome in subjects without fatty liver disease. Gastroenterol Res. Pract., 2017, vol. 2017, pp. 9279836. DOI: 10.1155/2017/9279836

61. Wang H., Chen Y., Guo X., Chang Y., Sun Y. Usefulness of cardiometabolic index for the estimation of ischemic stroke risk among general population in rural China. Postgrad Med., 2017, vol. 129, no. 8, pp. 834-841. DOI: 10.1080/00325481.2017.1375714

62. Rashid N., Nigam A., Saxena P., Jain S.K., Wajid S. Association of IL-1 $\beta$, IL-1Ra and FABP1 gene polymorphisms with the metabolic features of polycystic ovary syndrome. Inflamm Res., 2017, vol. 66, no. 7, pp. 621-636. DOI: 10.1007/s00011-017-1045-3

63. Drapkina O.M., Shepel R.N., Shalnova S.A., Deev A.D., Balanova Y.A., Evstifeeva S.E. [et al.]. Anthropometric Indices and Diabetes Mellitus Type 2 in Russian Population. Rational Pharmacotherapy in Cardiology, 2018, vol. 14, no. 5, pp. 725-732.

64. Shalnova S.A., Deev A.D., Muromtseva G.A., Balanova J.A., Imaeva A.E., Kapustina A.V., Evstifeeva S.E. [et al.]. Relation of anthropometric indexes and coronary heart disease. Cardiovascular Therapy and Prevention, 2018, vol. 17, no. 3, pp. 11-16.

65. Khripun I.A., Vorob'ev S.V., Kogan M.I. A new marker of metabolic disorders in men with type 2 diabetes. Meditsinskii vestnik Yuga Rossii, 2016, no. 1, pp. 84-86 (in Russian).

66. Kornoukhova L.A. Value of cardiovascular disorders' predictors in patients with abdominal obesity, nonalcoholic fatty liver disease and various metabolic syndrome components. Meditsinskii alfavit, 2017, vol. 1, no. 6, pp. 51-56 (in Russian).

67. Lwow F., Jedrzejuk D., Milewicz A., Szmigiero L. Lipid accumulation product (LAP) as a criterion for the identification of the healthy obesity phenotype in postmenopausal women. Exp. Gerontol., 2016, vol. 82, pp. 81-87. DOI: 10.1016/j.exger.2016.06.007 
68. Du T., Yu X., Zhang J., Sun X. Lipid accumulation product and visceral adiposity index are effective markers for identifying the metabolically obese normal-weight phenotype. Acta. Diabetol., 2015, vol. 52, no. 5, pp. 855-863. DOI: 10.1007/s00592-015-0715-2

69. Lin H., Zhang L., Zheng R., Zheng Y. The prevalence, metabolic risk and effects of lifestyle intervention for metabolically healthy obesity: a systematic review and meta-analysis: A PRISMA-compliant article. Medicine (Baltimore), 2017, vol. 96, no. 47, pp. e8838. DOI: 10.1097/MD.0000000000008838

Kaneva A.M., Bojko E.R. Lipid accumulation product or lap as an up-to-date clinical biochemical marker of human obesity. Health Risk Analysis, 2019, no. 2, pp. 164-173. DOI: 10.21668/health.risk/2019.2.18.eng

Received: 21.01.2019

Accepted: 03.06.2019

Published: 30.06.2019 